Article History:

Received: June 10, 2020

Revised: August 14, 2020

Accepted: August 24, 2020 https://doi.org/10.3126/pycnjm.v13i1.31491

PYC Nepal Journal of Management

Vol. XIII, No. 1, Page: 5-16

\title{
Eliciting the Determinants of Management Specialization Course Selection: A Consumer Behaviour Perspective
}

\author{
Shankar Kumar Shrestha' \\ Bikash Shrestha ${ }^{2}$ \\ (1) ORCID: 0000-0002-1081-461X
}

\begin{abstract}
This study utilizes a survey of TU BBA students studying in $8^{\text {th }}$ semester in an effort to understand how they choose their specialization courses by incorporating the attitude formation theory from a consumer behavior perspective. The study used multi stage sampling technique from 10 out of 25 TU BBA campuses. The sample size of the study is 114 students specializing the banking and finance, and sales and marketing in $8^{\text {th }}$ semester. The sample size is sufficient at alpha level (0.05), power (0.8) and anticipated effect size of 0.1 for the hierarchical regression with two and three number of predictors in last two models of the study and for performing $t$ test. The study demonstrated that the GPA in math and FPC underpin the course major decision of students vary significantly between finance and marketing specializing. The findings of this study indicate that students who choose banking and finance as a course major have higher confidence in their strength in mathematics. The study further concludes that students in choosing a higher education program give relatively great importance to various labor market aspects.
\end{abstract}

Key words: Individual factor, GPA, social factor, future prospect consideration, selection, specialization course

1. Dr. Shrestha is an Associate Professor of Statistics at Public Youth Campus, Tribhuvan University, Nepal. He can be reached at shanker.shrestha@pyc.tu.edu.np

2. Mr. Shrestha is a Lecturer of management at Public Youth Campus, Tribhuvan University, Nepal. He can be reached at bikash.shrestha@pyc.tu.edu.np 


\section{GENERAL BACKGROUND}

The present study attempts to reveal the choice decision of the BBA students concerning their selection of specialization courses in 7 th semester utilizing the attitude formation theory of Radford and Govier (1991). The authors asserted a change in one component of the system i.e. components of attitude (affective, behavior and cognitive) should produce changes in the other components (choice) in order to maintain consistency. In fact, education is an integral part in the development of human capital, which provides knowledge and skills used to meet the diverse needs of individuals and societies around the world (Becker, 1983). Hawani (2005) stressed a career in management has become of prime importance, as management itself is a very wide discipline with vast areas of specialization to choose. The choice of a college courses as specialization is one of the most important decisions a prospective college student makes (Brown, 2004). Moogan and Baron (2003) divided the variables that influence student choices in two categories: university and program characteristics, and the influencers of choice such as the sources of information that influences the students' decision-making.

There has been an extensive research conducted on students' decision making regarding their programs and universities (e.g. Vrontis, Thrassou, \& Melanthiou, 2007; Chakrabarti, 2009; Cavus, Geri, \& Turgunbayeva, 2015). Management itself is a very wide discipline; hence, students who choose management as a career step into the discipline with a question as to which major specialization to choose. Thus, other research papers focused on student's choices made during their studies (Newell, Titus, \& West, 1996; Hugstad, 1997; Petruzzellis \& Romanazzi, 2010; Arevalo \& Flores, 2016). Further, Anojan and Nimalathasan (2013) asserted selection of the major could be a stressful and pressurizing job because students do not make this decision in vacuum: numerous factors are influencing this decision

General Bachelor of Business Administration (BBA) of Tribhuvan University has been offering the four specialization courses in $7^{\text {th }}$ and $8^{\text {th }}$ semester. The specialization area of courses consist of banking \& finance, industry and services management, micro enterprise management, and sales and marketing management. However, the TU BBA students have been selecting the only two courses among the alternatives provided, i.e. banking and finance, and sales and marketing (Examination Controller Division, 2019). Even though course choice can be very influential in determining a student's self-image and future career path and determine the offerings of the higher education institutions, there is not any systematic evidence that provides insight into this critical decision in Nepalese context. This leads to the need for this study to determine the factors that influence undergraduate student's choice of specialization of TU BBA courses.

\section{OBJECTIVE OF THE STUDY}

Due to the increasing competitive forces with the increased institutions of higher education in Nepal, marketers need to be more aware of the underlying factors considered 
by students when choosing specialization in the undergraduate courses. Thus, study sought to determine the antecedents of selecting specialization course by TU BBA students specializing in banking and finance, and sales and marketing and identify the most influential determinant among the variables under study. In addition, the study also attempts to verify the existences of difference in past academic performance across the management undergraduate students specializing in banking and finance, and sales and marketing.

\section{THEORETICAL REVIEW}

The theoretical foundation of the study lies on the attitude formation theory by Radford and Govier (1991). According to the authors, the components in the triadic model of attitude formation were affective, behavior and cognitive. The implication of the triadic model is that these three components form a system and are interdependent. Further, the authors comprehended about the existence of close relationship between the cognitive and affective components of attitudes. The affective component encompasses our positive or negative emotions about something, that is, how we feel about it. The behavior component consists of a predisposition or intention to act in a particular manner that is relevant to our attitude. Finally, the cognitive component refers to the belief and thoughts we hold about the object of our attitude. Thus, the study incorporates the subject matter onto attitude formation theory, views students view on finance or marketing specialization as a subject involving talent, and hence this forms an attitude. Students' attitude toward specialization subjects may consist of positive emotions (the affective component). An intention to drop or proceed with specialization subjects (the behavior component) and the belief that specialization choice (finance and vice versa) is for talented students (the cognitive component) reflects negative emotions.

\section{LITERATURE SURVEY}

Beggs, Bantham, and Taylor (2008) defined a good selection of business course specialization as the major best capable of helping the student to achieve their educational and post-education goals, and the one which provides a match between the students' abilities and interest. The present review restricts itself to studies that deal with factors that determine the specialization choice of the student from the marketing perspective discussing about the specialization choice (outcome variable) and three different explanatory variables: social factor (SF), future prospect consideration (FPC) and individual factor i.e. past academic performance.

From a marketing perspective, choosing specialization or major subjects offers students the possibility to customize their undergraduate bachelor program in such a way that it reflects their personal ambitions and interests (Naidoo \& Jamieson, 2005). Regarding the student choice behavior, there is a growing research interest on how the students, as consumers, make their choices in higher education. Related to this is a growing research interest on how students, as consumers, make their choices 
in higher education (Newman \& Jahdi, 2009). Research on student choice behavior focuses on different choices students make in order to shape their career in higher education.

Robertson and Rossiter (1974) demonstrated that there are two major types of influence, first, direct influence, which is based directly on the decision maker's own needs and second, indirect influence in which the decision maker takes another family member's needs indirectly into account. Family, peers and other salient individuals play an important indirect role in the choice of specialization of a student (Owen \& Jensen, 2004). Similarly, friends are also an important influential factor; students are attracted towards those fields in which their friends had specialized (Dlamini, 1993). Finally, professionals such as head teachers, teachers, lecturers, instructors, counsellors, and auxiliary staff are said to be responsible for a student's choice of a specialization (Babad \& Tayeb, 2003; Tsikati, Dlamini, \& Masuku, 2016; Tsikati, 2018).

Schuster and Costantino (1986) comprehended that the future prospect considerations include many factors including career development, employment opportunities, compensation, job options, job security and occupational prestige. Job consideration such as prospect of employment, high income, and pleasant working conditions is one of the major factors influencing the choice of a subject specialization (Dlamini, 1993). Adopting experimental approach, Arcidiacono, Hotz, \& Kang (2012) collected information from students about their expected earnings in the current chosen majors and in counterfactual majors and found that both expected earnings and students' abilities in different majors are important determinants of student's choice of a major.

Robertson and Rossiter (1974) demonstrated that the decision maker takes the personal needs as a source of direct influence. The effect of factors related to personal conditions has normally larger impact on the student's decision-making process regarding their selection of specialization courses. Personal considerations include a student's needs and interest, their mental ability level, goals and motivations (Babad \& Tayeb, 2003). Dlamini (1993) reported that the subjects taken at high school and the grade achieved, influenced the student' choice of specialization. Whitley and Porter (1998), and Turner and Bowen (1999) provided the same findings with the evidence of ability sorting across majors by SAT scores. Similarly, Geiger and Ogilby (2000) found that traditional perceptions of precision and order in the profession discouraged more creative individuals from majoring the accounting.

\section{RESEARCH FRAMEWORK}

The theory of attitude formation advanced by Radford and Govier (1991) and the review of literature guided the formulation of the conceptual framework on the antecedents of specialization choice among the undergraduate students. The conceptual framework shows that future prospect consideration (employment opportunities, compensation and job options), social factor (parental influence, peer pressure and role model's influence), 
and individual factor (past academic performance i.e. GPA in math in first semester of the course) are determinants of students' specialization choice in the areas of banking and finance, and sales and marketing management. Feldman (1990) contended that multiple elements found in a given system have profound influences on choice. The framework of the study is as:

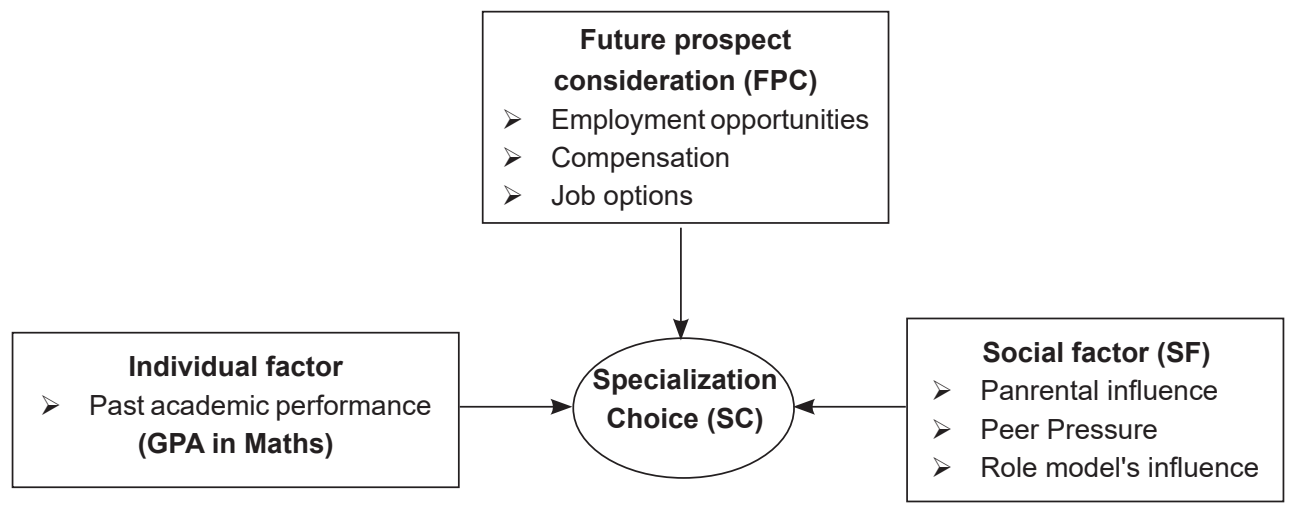

Figure 1. Research framework

\section{RESEARCH METHODOLOGY}

The study has employed causal research design and hierarchical regression as a tool to measure the effect of SF, FPC and past academic performance on specialization choice of finance or marketing in an order of hierarchy. The entire Tribhuvan University affiliated campus offering BBA programs, operating $8^{\text {th }}$ semester as of 2019 and offering any two different area of specialization were the population of the study. There were 28 such campuses and three campuses were offering only one area of specialization without any choices. Therefore, the population of the study was 25 campuses with 1528 students in total, studying banking and finance, and sales and marketing as the students have been selecting only those two courses among the four areas of specializations provided (Examination Controller Division, 2019). The population of the study is as in Appendix 1.

The study used multistage sampling. In first stage, the study selected 10 campuses using simple random methods including the campuses of different strata of ownership in nature (government and private campuses) and location of the campus (inside and outside Kathmandu). In the second stage, students studying the $8^{\text {th }}$ semester in TU BBA from the sample campuses were sent Microsoft forms in the Facebook page of each sample campuses in the month of March 2019. In overall, 114 forms were returned back by the mid of April 2019 and it was the final sample size of the study. The sample size is equal as recommended by (Soper, 2020) which was 114 at alpha level of 0.05 , power of 0.8 and anticipated effect size of 0.1 for employing the hierarchical regression with two and three number of predictors in last two models. The sample of the study is as in Appendix 2. 
The study measured the latent variables using the six, five and four items for social factors, future prospect consideration and specialization choice in a seven point Likert scale as measured by Owino and Odundo (2016) with some amendments as per the necessity for this study as per the recommendation of Kombo and Tromp (2011). The SF included the items about parental influence, peer pressure and role model's influence whereas future prospect consideration included future employment opportunities, expected compensation and future jobs availability. The mean value of SF, FPC and SC for each cases were determined to analyze the data. The variable individual factor is measured with the proxy variable past academic performance i.e. GPA in business mathematics in first semester of the course as per the study of Dlamini (1993). The internal consistency values $0.600,0.605$ and 0.603 of the variables SF, FPC and SC with six, five and four items is satisfactory and moderate for the further analysis (Griethuijsen, et al., 2014; Taber, 2018)

\section{DATA ANALYSIS}

This part of the study describes the various descriptive and inferential statistics for analyzing the objectives of the study. Panel A in Table 1 depicts the descriptive statistics of all 114 samples for the variables under study.

Table 1

Descriptive statistics

\begin{tabular}{|c|c|c|c|c|c|c|}
\hline \multicolumn{7}{|c|}{ Panel A: Descriptive statistics for all sample } \\
\hline Variables & $\mathrm{N}$ & Mean & Range & $\begin{array}{l}\text { Std. Error of } \\
\text { Mean }\end{array}$ & Skewness & $\begin{array}{c}\text { Std. Error of } \\
\text { Skewness }\end{array}$ \\
\hline$\overline{\mathrm{SF}}$ & 114 & 4.83 & 2.50 & 0.05 & 0.42 & 0.23 \\
\hline FPC & 114 & 5.88 & 2.40 & 0.05 & -0.52 & 0.23 \\
\hline GPA & 114 & 3.17 & 2.34 & 0.05 & -0.85 & 0.23 \\
\hline SC & 114 & 5.24 & 4.00 & 0.07 & -1.29 & 0.23 \\
\hline \multicolumn{7}{|c|}{ Panel B: Descriptive statistics for finance specialization students } \\
\hline SF & 56 & 4.83 & 2.17 & 0.07 & 0.39 & 0.32 \\
\hline FPC & 56 & 5.83 & 2.20 & 0.07 & -0.33 & 0.32 \\
\hline GPA & 56 & 3.22 & 1.95 & 0.06 & -0.51 & 0.32 \\
\hline $\mathrm{SC}$ & 56 & 5.28 & 3.00 & 0.09 & -0.60 & 0.32 \\
\hline \multicolumn{7}{|c|}{ Panel C: Descriptive statistics for marketing specialization students } \\
\hline$\overline{S F}$ & 58 & 4.82 & 2.50 & 0.07 & 0.46 & 0.31 \\
\hline FPC & 58 & 5.93 & 2.40 & 0.08 & -0.72 & 0.31 \\
\hline GPA & 58 & 3.13 & 2.34 & 0.07 & -1.01 & 0.31 \\
\hline SC & 58 & 5.20 & 4.00 & 0.11 & -1.70 & 0.31 \\
\hline
\end{tabular}


The outputs show the data are about symmetric as the values for skewness and kurtosis between -1.96 and +1.96 are considered acceptable in order to prove normal univariate distribution (Gravetter \& Wallnau, 2014). Similarly, panel B and C highlights the descriptive statistics of 56 and 58 students specializing in banking and finance, and sales and marketing and the data seems to follow the normal univariate distribution.

The Table 2 depicts the regression analysis in a hierarchical order. The Model 1 includes SF as the predictor and has negative and insignificant effect on specialization choice. Similarly, after adding FPC in model 1, still both the variables have negative insignificant effect on the specialization choice. However, in the final model after adding GPA in model 2, GPA has the positive significant effect in the specialization choice 1.262 (sig value $=0.001)$. This is the evidence of significant effect of individual factor on selecting the major choice at least among the TU BBA students. The result of $t$ test in Appendix 3 supports this result. The $t$ test result indicates the mean values of GPA in math is higher for the students specializing in finance compare to the students specializing in sales and marketing and supports the GPA in math has significant effect on choice of finance as major. The result of Table 3 reveals the inclusion of the predictor GPA in model 3 is justifiable as the R square value is 0.653 higher than in the Model 2 and change in $\mathrm{F}$ statistics is also significant to support the results of the regression result.

Table 2

Hierarchical regression analysis

\begin{tabular}{|c|c|c|c|c|c|c|c|c|}
\hline \multirow{2}{*}{ Model } & \multirow{2}{*}{ Variables } & \multicolumn{2}{|c|}{$\begin{array}{l}\text { Unstandardized } \\
\text { Coefficients }\end{array}$} & \multirow{2}{*}{ Sig. } & \multicolumn{2}{|c|}{ Collinearity Statistics } & \multirow{2}{*}{$\frac{\text { ANOVA }}{\mathrm{F}}$} & \multirow{2}{*}{ Sig. } \\
\hline & & B & SE & & Tolerance & VIF & & \\
\hline \multirow{3}{*}{1} & (Constant) & 5.926 & 0.634 & 0.001 & & & \multirow{3}{*}{1.18} & \multirow{2}{*}{0.280} \\
\hline & SF & -0.142 & 0.131 & 0.280 & 1 & 1 & & \\
\hline & (Constant) & 6.176 & 1.009 & 0.001 & & & & \\
\hline \multirow[t]{3}{*}{2} & SF & -0.146 & 0.132 & 0.270 & 0.991 & 1.009 & \multirow[t]{2}{*}{0.64} & \multirow{2}{*}{0.531} \\
\hline & FPC & -0.039 & 0.123 & 0.750 & 0.991 & 1.009 & & \\
\hline & (Constant) & 0.794 & 0.696 & 0.257 & & & \multirow{4}{*}{72.49} & \\
\hline \multirow{3}{*}{3} & SF & -0.096 & 0.077 & 0.217 & 0.989 & 1.011 & & \multirow{3}{*}{0.000} \\
\hline & FPC & 0.154 & 0.073 & 0.038 & 0.959 & 1.043 & & \\
\hline & GPA & 1.262 & 0.086 & 0.001 & 0.967 & 1.034 & & \\
\hline
\end{tabular}

a Dependent Variable: SC

Conversely, the effect of FPC is positive and significant 0.154 ( $p$ value $=0.038$ ) in contrast to -0.039 in Model 2. The data fits the model well as the ANOVA F value is significant at 0.001 level of significance. Further, the collinearity statistics reveal the non-existence of multicollinearity in the final model of hierarchical regression analysis. Finally, Figure 2 displays the residual statistics of the final model and seems to fulfill the assumption of linear regression analysis, as the distribution is symmetric in shape. 
12 I PYC Nepal Journal of Management, August 2020 Vol. XIII, No. 1

Table 3

$R$ square and $F$ change statistics

\begin{tabular}{ccccccccc}
\hline & & \multirow{2}{*}{$\begin{array}{c}\mathrm{R} \\
\text { Model }\end{array}$} & $\mathrm{R}$ & Std. Error of the & \multicolumn{5}{c}{ Change Statistics } \\
\cline { 5 - 9 } & & Square & Estimate & R2 Change & F Change & df1 & df2 & $\begin{array}{c}\text { Sig. F } \\
\text { Change }\end{array}$ \\
\hline 1 & $.102 \mathrm{a}$ & 0.010 & 0.75923 & 0.01 & 1.18 & 1 & 112 & 0.280 \\
2 & $.106 \mathrm{~b}$ & 0.011 & 0.7623 & 0.001 & 0.102 & 1 & 111 & 0.750 \\
\hline 3 & $.815 \mathrm{c}$ & 0.664 & 0.44635 & 0.653 & 213.752 & 1 & 110 & 0.000 \\
\hline
\end{tabular}

a Predictors: (Constant), SF

b Predictors: (Constant), SF, FPC

c Predictors: (Constant), SF, FPC, GPA

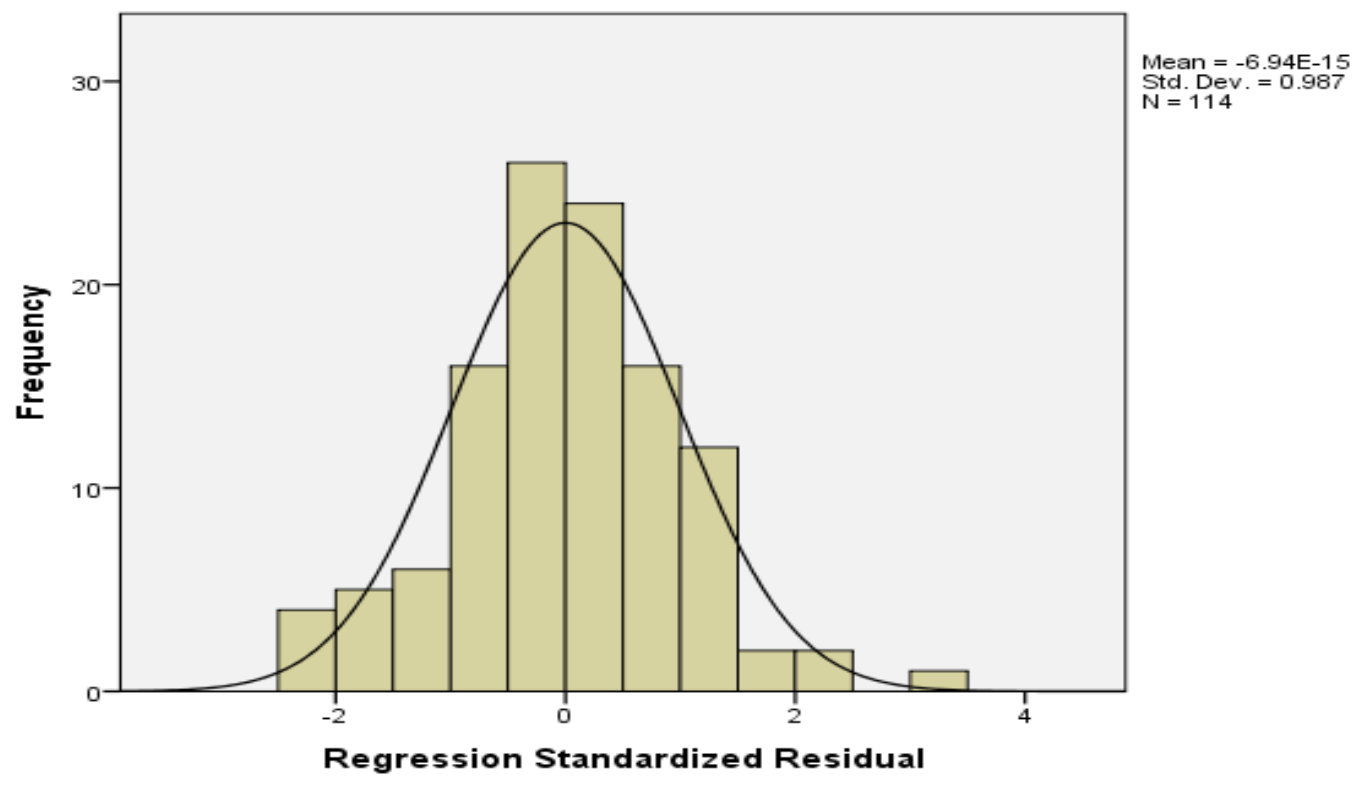

Figure 2. Regression standardized residual

\section{DISCUSSION AND CONCLUDING REMARKS}

This research utilizes a survey of TU BBA students studying in $8^{\text {th }}$ semester in an effort to understand how they choose their specialization field of study by incorporating the attitude formation theory. Furthermore, this study also aimed at investigating the relative and significant importance of the antecedents under study. The results indicate the most important determinant in the choice of major are individual factor measured by proxy variable GPA in math (past academic performance) and FPC. The findings of this study further demonstrate that the GPA in math underpin the course major decision of students vary significantly between finance and marketing specializing. Students with high GPA in math (past academic performance) prefer the banking and finance option in compare to 
low GPA score who prefer sales and marketing. The findings of this study indicate that students who choose banking and finance as a course major have higher confidence in their strength in mathematics. The study supports the findings of Dlamini (1993), Dynan and Rouse (1997), Krishnan, Bathala, Bhattacharya, and Ritchey (1997), Henebry and Diamond (1998), Didia \& Hasnat (1998), Whitley and Porter (1998), Turner and Bowen (1999), Geiger and Ogilby (2000), Babad and Tayeb (2003) and Tsikati (2018). Thus, the study concludes that the formation of positive attitude (affective attitude formation) among the students with high GPA in math views finance specialization as a subject involving talent and thus choose it as a major at least among the TU BBA students.

In addition to the variable GPA, the result indicated the positive significant impact of FPC on specialization choice of banking and finance and sales and marketing among the management undergraduate students in Nepal. The findings is in line with the results of Dlamini (1993), and Arcidiacono, Hotz, and Kang (2012). From this, the study further concludes that students in choosing a higher education program give relatively great importance to various labor market aspects supporting the existence of cognitive component in attitude formation and choosing the specialization course accordingly. However, the results indicated that undergraduate management Nepalese students are not sensitive to referents' opinions basically parents, peers and role models in choosing their specialization courses of banking and finance, or sales and marketing. The result contradicts the findings of Dlamini (1993), Babad and Tayeb (2003), Owen and Jensen (2004), Tsikati, Dlamini, and Masuku (2016), and Tsikati (2018) who had observed the significant effect of family, friends, professionals such as head teachers, teachers, lecturers, instructors, counsellors, and auxiliary staff significantly affect in selecting students specialization choices.

\section{IMPLICATIONS AND FUTURE DIRECTION OF THE STUDY}

The results of this study have implications for universities and campuses offering management education from marketing perspectives especially in designing and maintenance of the specialization courses portfolio and developing the system of providing right information to the students in selecting their major. However, since learning value is a subjective aspect that differs per student, the study recommends universities and campuses to investigate students' needs for specialization courses portfolio, which will contribute to their future career opportunities. In addition, the results of this study have implications for developing the appropriate system of delivering information to students for selecting their major in their undergraduate management programs in Nepal.

Decision-making variables indeed are only one aspect of a broader theory on students' major selection. Future research should focus on replication of this study and aim at other aspects of students' decision-making, as replication adds to the generalizability of the model and deals with the selection of the sample and / or the research strategy. In order to improve the generalizability, the future study can replicate by sampling the undergraduate management students from other management courses from the university 
and other universities as well. Testing the model in an experimental setting would add more values to the existing body of knowledge in this area. Furthermore, to arrive at a larger theory of students' decision-making it is advised to investigate other aspects of the decision making process using some other research design. The future study also could be directed towards observing the effect of social factor and future prospect consideration by controlling the effect of the GPA by considering it as the covariate.

\section{REFERENCES}

Anojan, V., \& Nimalathasan, B. (2013). Factors influencing in career choice of second year undergraduate students: A case study of faculty of management studies and commerce. International Journal of Social Science and Interdisciplinary Research, 2(11), 16-25.

Arcidiacono, P. V., Hotz, J., \& Kang, S. (2012). Modeling college major choices using elicited measures of expectations and counterfactuals. Journal of Econometrics, 166(1), 3-16.

Arevalo, A. R., \& Flores, L. Y. (2016). Nontraditional career choices of Mexican American men: Influence of acculturation, enculturation, gender role traits, self-efficacy, and interests. Journal of Latina Psychology, 4(3), 142-157.

Babad, E., \& Tayeb, A. (2003). Experimental analysis of student course selection. British Journal of Educational Psychology, 73(3), 373-393.

Becker, G. S. (1983). Human capital: A theoretical and empirical analysis with special reference to education (3rd ed.). Chicago: University Press of Chicago.

Beggs, J. M., Bantham, J. H., \& Taylor, S. (2008). Distinguishing the factor's influencing college student's choice of major. College Student Journal, 42(2), 381-394.

Brown, M. T. (2004). The career development influence of family of origin: Considerations of race/ ethnic group membership and class. The Counseling Psychologist, 32(4), 587-595.

Cavus, S., Geri, S., \& Turgunbayeva, K. (2015). Factors affecting the career plans of university students after graduation. International Journal of Humanities and Social Science, 5(5), 94-99.

Chakrabarti, A. (2009). Determinants of participation in higher education and choice of disciplines: Evidence from urban and rural Indian youth. South Asia Economic Journal, 10(2), 371-402.

Dlamini, M. P. (1993). Predictors of college students' reasons for pursuing programme of study and enrolling in tertiary institutions in Swaziland. UNISWA Journal of Agriculture, 2(1), 64-69.

Examination Controller Division. (2019). Retrieved from Tribhuvan University Examination Controller Division Website: https://www.fomecd.edu.np/examinationandresult

Feldman, R. O. (1990). Understnding psychology. New York: McGrawHill.

Geiger, M. A., \& Ogilby, S. M. (2000). The first course in accounting: students' perceptions and their effect on the decision to major in accounting. Journal of Accounting Education, 18(1), 63-78.

Gravetter, F., \& Wallnau, L. (2014). Essentials of statistics for the behavioral sciences. Wardsworth: Belmont Press.

Griethuijsen, R. V., Eijck, M. V., Haste, H., Brok, P. D., Skinner, N. C., Mansour, N., . . BouJaoude, S. (2014). Global patterns in student's views of science and interest in science. Research in Science Education, 45(4), 581-603. doi: 10.1007/s11165-014-9438-6

Hawawini, G. A. (2005). The future of business schools. Journal of Management Development, 24(9), 770-782. doi:10.1108/02621710510621286

Hugstad, P. (1997). Marketing the marketing major. Journal of Marketing Education, 19(1), 4-13. doi:10.1177/027347539701900102

Kombo, K. D., \& Tromp, D. (2011). Proposal and thesis writing: An introduction. Nairobi: Paulines Publishing Africa. 
Krishnan, V. S., Bathala, C. T., Bhattacharya, T. K., \& Ritchey, R. (1997). Teaching the introductory finance course: What can we learn from student perceptions and expectations? Financial Practice and Education, 9(1), 70-82.

Lent, R. W. (2005). A social cognitive view of career development and counseling. In D. Brown, \& R. W. Lent, Career development and counseling: Putting theory and research to work. Hoboken, NJ: John Wiley \& Sons Inc.

Moogan, Y. J., \& Baron, S. (2003). An analysis of student characteristics within the student decision making process. Journal of Further and Higher Education, 27(3), 271-287.

Naidoo, R., \& Jamieson, M. (2005). Empowering participants or corroding learning?: Towards a research agenda on the impact of student consumerism in higher education. Journal of Education Policy, 20(3), 267-281.

Newell, S. J., Titus, P. A., \& West, J. S. (1996). Investigating the undergraduate student decisionmaking process of selecting a business specialization: A comparison of marketing and nonmarketing business students. Journal of Marketing Education, 18(3), 57-67.

Newman, S., \& Jahdi, K. S. (2009). Marketisation of education: Marketing, rhetoric and reality. Journal of Further and Higher Education, 33(1), 1-11.

Owen, A. L., \& Jensen, E. J. (2004). Learning about learning: Student's course choice. doi:Owen, Ann L. and Jensen, Elizabeth, Learning About Learning: Students' Course Choice (Decemberhttp://dx.doi.org/10.2139/ssrn.651003

Owino, J. O., \& Odundo, P. A. (2016). Factors influencing Bachelor of Education arts students' selection of history as career subject. Universal Journal of Educational Research, 4(10), 2236-2243.

Petruzzellis, L., \& Romanazzi, S. (2010). Educational value: How students choose university?: Evidence from an Italian university. International Journal of Educational Management, 24(2), 139-158. doi:10.1108/09513541011020954

Radford, J., \& Govier, E. A. (1991). A textbook of psychology. London: Routledge.

Robertson, T. S., \& Rossiter, J. R. (1974). Children and commercialpPersuasion: An attribution theory analysis. Journal of Consumer Research, 1(1), 13-20.

Schuster, C. P., \& Costantino, P. (1986). Using marketing research to develop student recruiting strategies. NACTA Journal, 30(10), 5-9.

Soper, D. S. (2020). A priori sample size calculator for hierarchical multiple regression. Retrieved from https://www.danielsoper.com/statcalc/calculator.aspx?id=16

Taber, K. S. (2018). The use of Cronbach's alpha when developing and reporting research instruments in science education. Research in Science Education, 48(6), 1273-1296.

Tsikati, A. (2018). Factors influencing the choice of subject specialisation by students at teacher training institutions in Eswatini. Proceedings of the 17th BOLESWANA Biennial Research Symposium, (pp. 293-295). Windhoek. Retrieved from https://files.eric.ed.gov/fulltext/ EJ1222627.pdf

Tsikati, A., Dlamini, B. M., \& Masuku, M. (2016). Factors influencing the choice of an agriculture specialisation by college student teachers in Swaziland. Journal of Agricultural Studies, 4(1), 12-24.

Turner, S. E., \& Bowen, W. G. (1999). Choice of major: The changing (unchanging) gender gap. Industrial and Labor Relations Review, 52(2), 289-313.

Vrontis, D., Thrassou, A., \& Melanthiou, Y. (2007). A contemporary higher education studentchoice model for developed countries. Journal of Business Research, 60(9), 979-989.

Whitley, S., \& Porter, J. (1998). Student perceptions on subject selection, longitudinal perspectives from Queensland school. AARE Annual Conference. Adelaide. Retrieved from https://www.aare.edu.au/data/publications/1998/whi98262.pdf 
16 I PYC Nepal Journal of Management, August 2020 Vol. XIII, No. 1

\section{APPENDICES}

\begin{tabular}{|c|c|c|c|c|c|}
\hline Location & Ownership & $\mathrm{N}$ (Campus) & Category & $\begin{array}{c}\text { Sum } \\
\text { (Students) }\end{array}$ & Per cent \\
\hline \multirow{3}{*}{$\begin{array}{l}\text { Outside } \\
\text { Kathmandu }\end{array}$} & \multirow{3}{*}{ Government } & \multirow{3}{*}{4} & N_Fin & 150 & 65.50 \\
\hline & & & N_Mkt & 79 & 34.50 \\
\hline & & & N_Total & 229 & 100.00 \\
\hline \multirow{6}{*}{$\begin{array}{l}\text { Inside } \\
\text { Kathmandu }\end{array}$} & \multirow{3}{*}{ Government } & \multirow{3}{*}{6} & N_Fin & 311 & 74.76 \\
\hline & & & N_Mkt & 105 & 25.24 \\
\hline & & & N_Total & 416 & 100.00 \\
\hline & \multirow{3}{*}{ Private } & \multirow{3}{*}{15} & N_Fin & 465 & 52.66 \\
\hline & & & N_Mkt & 418 & 47.34 \\
\hline & & & N_Total & 883 & 100.00 \\
\hline
\end{tabular}

Appendix 2

Sample of the study

\begin{tabular}{|c|c|c|c|c|}
\hline \multirow{2}{*}{ Location } & \multirow{2}{*}{ Ownership } & \multirow{2}{*}{ Campus } & \multicolumn{2}{|c|}{ No. of students } \\
\hline & & & Fin_Major & Mkt_Major \\
\hline \multirow{5}{*}{$\begin{array}{l}\text { Outside } \\
\text { Kathmandu }\end{array}$} & \multirow{2}{*}{ Government } & Campus 1 & 5 & 3 \\
\hline & & Campus 2 & 6 & 8 \\
\hline & \multirow{4}{*}{ Governemnt } & Campus 3 & 7 & 4 \\
\hline & & Campus 4 & 2 & 6 \\
\hline & & Campus 5 & 5 & 6 \\
\hline \multirow{7}{*}{$\begin{array}{l}\text { Inside } \\
\text { Kathmandu }\end{array}$} & & Campus 6 & 12 & 7 \\
\hline & \multirow{4}{*}{ Private } & Campus 7 & 6 & 8 \\
\hline & & Campus 8 & 3 & 8 \\
\hline & & Campus 9 & 7 & 5 \\
\hline & & Campus 10 & 3 & 3 \\
\hline & \multicolumn{2}{|c|}{ Total Number } & 56 & 58 \\
\hline & \multicolumn{2}{|c|}{ Total per cent } & 49.12 & 50.88 \\
\hline
\end{tabular}

\section{Appendix 3}

Mean difference test of specialization choice across finance and marketing specializing students

\begin{tabular}{lcccccc}
\hline $\begin{array}{c}\text { Levene's Test for Equality of } \\
\text { Variances }\end{array}$ & $\mathrm{F}$ & Sig. & $\begin{array}{c}\text { Mean Difference } \\
(\mathrm{F}-\mathrm{M})\end{array}$ & $\mathrm{t}$ & $\mathrm{df}$ & $\begin{array}{c}\text { Sig. } \\
(2 \text {-tailed })\end{array}$ \\
\hline Equal variances assumed & 0.066 & 0.798 & 0.079 & 0.551 & 112 & 0.583 \\
Equal variances not assumed & & & 0.079 & 0.552 & 110.575 & 0.582 \\
\hline
\end{tabular}

